\title{
Optimization of Environmental Factors to Measure Physiological Parameters of Two Rose Varieties
}

\author{
Mohammed Ibrahim1,2, Manjree Agarwal', Giles Hardy', Muslim Abdulhussein3, \\ Yonglin Ren ${ }^{*}$
}

${ }^{1}$ School of Veterinary and Life Sciences, Murdoch University, Perth, Australia

${ }^{2}$ Faculty of Agriculture, University of Babylon, Babylon, Iraq

${ }^{3}$ Faculty of Agriculture, University of Kufa, Najaf, Iraq

Email:*y.ren@murdoch.edu.au

How to cite this paper: Ibrahim, M., Agarwal, M., Hardy, G., Abdulhussein, M. and Ren, Y.L. (2017) Optimization of Environmental Factors to Measure Physiological Parameters of Two Rose Varieties. Open Journal of Applied Sciences, 7, 585-595. https://doi.org/10.4236/ojapps.2017.710042

Received: October 1, 2017

Accepted: October 28, 2017

Published: October 31, 2017

Copyright $\odot 2017$ by authors and Scientific Research Publishing Inc. This work is licensed under the Creative Commons Attribution International License (CC BY 4.0).

http://creativecommons.org/licenses/by/4.0/

\begin{abstract}
Rose (Rosa hybrida L.) is one of the most important specialty cut flowers produced. Characterization of physiological variability in photosynthetic efficiencies, respiration rate and chlorophyll content is one of the greatest challenges in assessing rose net primary production of flowering, quality of cut flowers and other rose uses. Two modern rose varieties Floribunda and Hybrid Tea were used to optimize different methods for analysing physiological characteristics (photosynthesis rate, respiration rate and chlorophyll content). Many parameters were optimized, five different lights intensity were used $\left(600,900,1200,1500\right.$ and $\left.2000 \mu \mathrm{mol} \cdot \mathrm{m}^{-2} \cdot \mathrm{s}^{-1}\right)$ of which $1200 \mu \mathrm{mol} \cdot \mathrm{m}^{-2} \cdot \mathrm{s}^{-1}$ gave the highest photosynthesis rate. Five different measuring times were used (8 am, $10 \mathrm{am}, 12 \mathrm{pm}, 2 \mathrm{pm}$ and $4 \mathrm{pm}$ ) and $12 \mathrm{pm}$ was shown to be the optimum time for measuring photosynthesis rate. Among two different weather conditions (sunny day and cloudy day) sunny day was selected. For respiration rate two different measuring times ( 1 and 2 hours) after darkness were studied and 1 hour was chosen. Among three different times (10 am, $12 \mathrm{pm}$ and $2 \mathrm{pm}$ ) for measuring chlorophyll content, $12 \mathrm{pm}$ was selected. Using these optimized variables will allow researchers to collect robust and reproducible results to be obtained from different studies, and in turn lead to improved yields of horticultural plants.
\end{abstract}

\section{Keywords}

Rose, Hybrid Tea, Floribunda, Physiological Parameters, Photosynthesis, Respiration Rates 


\section{Introduction}

Roses plants (Rosa hybrid L.) Hybrid Tea Rose cv. Mr. Lincoln and Floribunda Rose cv. Iceberg are two of the most important ornamental flowering shrubby and odorous plants [1]. These two rose varieties (Hybrid Tea and Floribunda) are considered as modern roses and are very popular in Australia. They are common cultivated for gardening, cut flowers and industry use [2] [3]. Particularly, Hybrid Tea rose was the crossing between European and Chinese roses, while Floribunda is the result of crossing hybrid tea with Polyantha [4] [5]. Temperate zones of the northern hemisphere and Asia are where the majority of Rosa species are found [6]. Roses as commercial crops and are distributed worldwide. There are several natural environmental factors which affect the physiological parameters and production of rose flowers, but few systematic studies have been done on this aspect for rose production. A recent study by [7] on Hybrid Tea and Floribunda roses to optimize methods to analyze volatiles organic compounds was used. There are many physiological parameters which affect rose plant production (shoot-bending, leaves and cut flowers) such as rates of photosynthesis, transpiration, and respiration, together with stomatal conductance and stem water potential.

Photosynthesis is an important process in all plants, and especially for rose growers to improve the quality of cut flowers and whole rose plants, also for leaf area [8]. Leaf distribution pattern, and the amount of light all affect the photosynthesis rate rose plants [9] [10]. Some physiological and morphological changes occur under different light intensities leading to different growth responses [11]. A study by [12] showed that high quality cut flowers could be achieved by increased light intensity and photosynthesis rates. Moreover, a photosynthesis rate at $1500 \mu \mathrm{mol} \cdot \mathrm{mol}^{-1}$ light intensity increased the production of cut flowers [13]. Few studies have examined the effect of different light intensities on photosynthesis rate of rose plants, and there is no research on the optimization of light intensity, sampling time and weather condition on photosynthesis. Therefore, the optimization of these different photosynthesis parameters is important in order to optimize the health of rose plants and the production of flowers.

In addition to photosynthesis, respiration is another important process which effects the growth, development and production of rose plants [7]. Leaf dark respiration is among the most fundamental of plant physiological processes and plays a major role in the carbon cycle at a leaf and global scale [14]. Respiration rate is negatively correlated with tissue longevity in pre- and post-harvest plant physiology [15]. Furthermore, low respiration rate has been related to increased flower longevity in floriculture plants, for example, respiration rates have been related to the longevity of potted flowering chrysanthemum [16]. Respiration rate and chlorophyll content in rose leaves (Rosa hybrid) increased when the temperature and photosynthesis rate were high [17]. Likewise, [18] showed that high temperature increased respiration rate as well photosynthesis rate at $35^{\circ} \mathrm{C}$ 
which was measured under $\mathrm{CO}_{2}$ level on rose plants (Rosa hybrid). There is a relationship between the photosynthesis rate and chlorophyll content as plants tend to respond to ambient light by adjusting their chlorophyll content and composition [11]. Studying chlorophyll content in rose leaves showed rapid and high dynamical acclimation of leaves to the changing light, which in turn influenced photosynthesis and other physiological processes [19]. A study on marigold plants demonstrated that the chlorophyll content was high at mid-day with the application of growth regulators giving a high chlorophyll content as well as photosynthetic pigments [20]. A study by [21], reported that when trees leaves were exposed to low light they had lower chlorophyll content than those exposed to the high light.

The objectives of this study were to optimize: 1) light intensity, sampling time and weather conditions in rose plants for maximum photosynthesis; and 2) different measurement times for optimal respiration rate and chlorophyll content.

\section{Materials and Methods}

\subsection{Plant Material and Maintenance}

This research was conducted at Murdoch University, Western Australia in an evaporatively cooled glasshouse under a natural photoperiod and temperatures maintained between $18^{\circ} \mathrm{C} \pm 2{ }^{\circ} \mathrm{C}$ to $25^{\circ} \mathrm{C} \pm 2{ }^{\circ} \mathrm{C}$ during night and day, respectively, whilst the humidity was maintained at $60 \% \pm 2 \%$ and $75 \% \pm 2 \%$ day and night, respectively. Two rose cultivars (Hybrid Tea cv. Mr Lincoln) and (Floribunda cv. Iceberg) at flowering stage were used and these were purchased from Dawson's Garden World nursery (Perth, Western Australia). These were immediately transferred to free-draining plastic pots $24 \times 24 \mathrm{~cm}$ (diameter $\times$ height) in a 2:2:1 potting mix ( 2 parts composted pine bark, 2 parts course river sand and 1-part coco peat) purchased from W. A. Richgro Perth, Western Australia. There were 36 two-year-old rose plants in total. The plants were watered manually daily to container capacity. The rose pots were arranged in a factorial complete randomized design with two rose cultivars, three physiological characteristics (photosynthesis, respiration and chlorophyll contents) and three replicates plants for each treatment.

\subsection{Photosynthesis Measurements}

A photosynthesis system (ADC; BioScientific, LCpro+, UK, serial number 32125) with a red/blue LED light source (LCpro+) mounted onto a 6- $\mathrm{cm}^{2}$ clamp-on leaf chamber was used to determine photosynthesis rate under various light intensities. Three fully expanded and developed leaflets for each plant (developed between September and November 2016) were used. The instrument programme was configured to detect the sum of three readings which was then averaged. Five levels of light intensity $\left(600,900,1200,1500\right.$ and $\left.2000 \mu \mathrm{mol} \cdot \mathrm{m}^{-2} \cdot \mathrm{s}^{-1}\right)$ were used. In total, 108 leaflets were investigated for both rose varieties. Also, five different times were optimized ( $8 \mathrm{am}, 10 \mathrm{am}, 12 \mathrm{pm}, 2 \mathrm{pm}$ and $4 \mathrm{pm}$ ) to determine 
the optimum time for measuring photosynthesis during the day. In addition, measurements were taken on three sunny days and three cloudy days.

\subsection{Respiration Measurements}

The respiration rate measurements were determined with an ADC (BioScientific, UK, serial number 32125) using a $6 \mathrm{~cm}^{2}$ area of a leaf that had been dark adapted for 1 and 2 hours. Measurements after 1 and 2 hours of dark acclimation were recorded following a low intensity pulse. Each measurement was replicated three times.

\subsection{Chlorophyll Measurements}

Chlorophyll content was determined with a CCM-200 plus, Chlorophyll Content Meter (serial number NH 03051, Opti-Sciences, USA). Three different times (10 am, $12 \mathrm{pm}$ and $2 \mathrm{pm}$ ) were studied for measuring chlorophyll content from two rose varieties. Fully expanded, healthy leaflets replicated three times were used for each rose and time combination.

\subsection{Statistical Analyses}

All physiological parameters were analysed by using Statistical Analysis Software $\left(\mathrm{SAS}^{\circledR}\right)$ University edition, and the results were presented by analysis of variance (ANOVA). Least Significant Difference (LSD) was used and the level of statistical significance was $\mathrm{P} \leq 0.05$.

\section{Results and Discussion}

\subsection{Optimization of Light Intensity for Maximum Photosynthesis}

The total photosynthesis rate increased from 600 to $1200 \mu \mathrm{mol} \cdot \mathrm{m}^{-2} \cdot \mathrm{s}^{-1}$, but there after decreased at 1500 and $2000 \mu \mathrm{mol} \cdot \mathrm{m}^{-2} \cdot \mathrm{s}^{-1}$ for both rose varieties. Consequently, $1200 \mu \mathrm{mol} \cdot \mathrm{m}^{-2} \cdot \mathrm{s}^{-1}$ was selected as the optimum light intensity for photosynthesis measurements Figure 1. In contrast, the study by [13] on rose plants (Rosa hybrid L.) showed maximum photosynthesis rate $1500 \mu \mathrm{mol} \cdot \mathrm{mol}^{-1}$ and this led to an increase in cut flowers production. Many studies have shown how environmental factors affect physiological processes in plants, such as temperature, light intensity, $\mathrm{CO}_{2}$ concentration and photosynthesis process [22]. An optimum light intensity leads to increased rose cut flower production and this is generally ascribed to an increased source of carbohydrates [23]. In another study, the maximum photosynthesis rate was reached at a light intensity of $750 \mu \mathrm{mol} \cdot \mathrm{m}^{-2} \cdot \mathrm{s}^{-1}$ in rose plants (Rosa rugosa) [24]. Furthermore, [25] indicated that using a light intensity of $180.7 \mu \mathrm{mol} \cdot \mathrm{m}^{-2} \cdot \mathrm{s}^{-1}$ significantly increased the photosynthesis rate and production of cut flowers for rose plants.

\subsection{Analysis of Photosynthesis with Five Sampling Times}

There were significant differences between the five sampling times and the sampling time at $12 \mathrm{pm}$ was selected because the highest photosynthesis rate was 


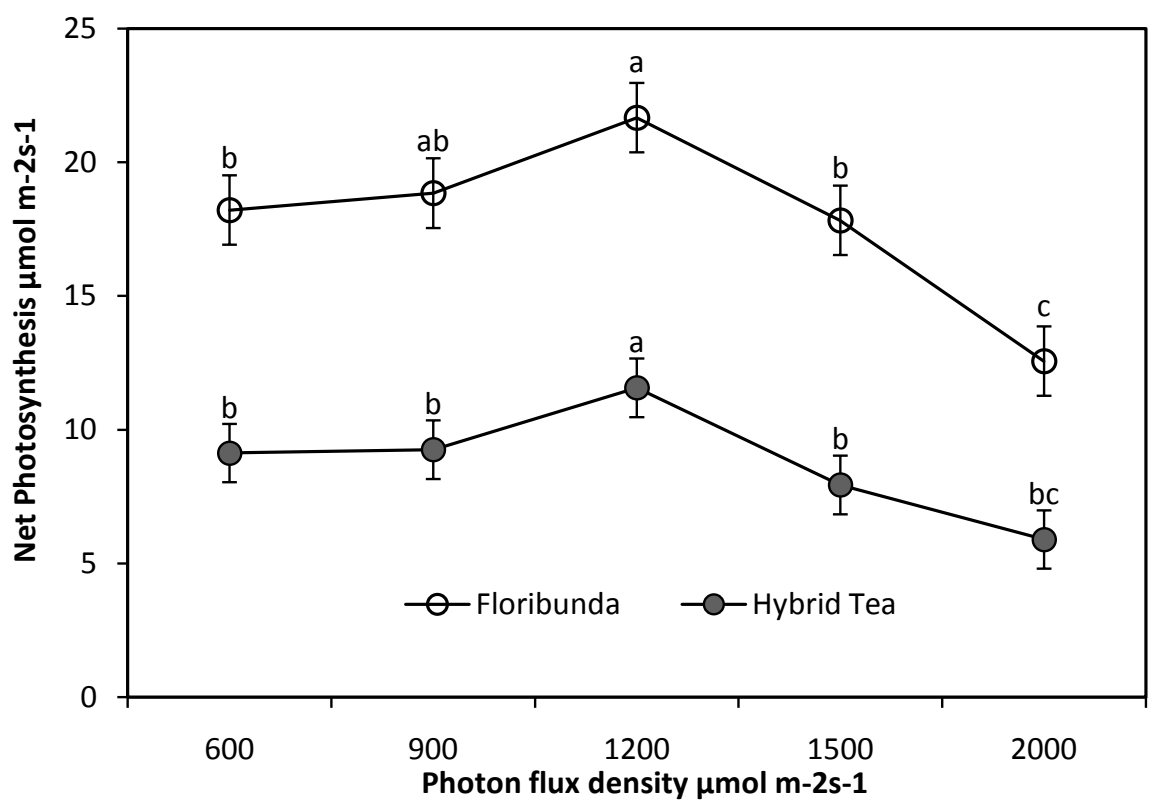

Figure 1. Evolution of photosynthesis rate with exposure to different light intensity of two rose varieties (error bars were LSD at $\mathrm{P} \leq 0.05$ ).

recorded at this time compare to the times at $\mathrm{P}$ value of 0.05 Figure 2 . The photosynthesis rate increased from 8 am to $12 \mathrm{pm}$ and then it decreased with $2 \mathrm{pm}$ and $4 \mathrm{pm}$ Figure 2. Photosynthesis decreases as light intensity decreases, and increases significantly high light intensities for rose plants (Rosa hybrida "Haban") [10]. Similar observations were made by [20] on marigold plants, where increases in showed that light intensity increased photosynthesis, and for rose plants [26]. A decrease in light level below the optimum level will lead to reduced photosynthesis and in turn yield reduction in roses [27].

\subsection{Effect of Weather Conditions on Photosynthesis Rate}

There were significant differences in photosynthesis between sunny and cloudy days, with sunny days were chosen Figure 3 for subsequent measurements. This is because sunny days have high levels of light intensity leading to increased photosynthesis rates. Similar observations have been made in vines exposed to sunny days compared to the cloudy days [28], for Maple trees [29], and for two Populus clones plants [30]. To date, no research has been conducted on rose plants and optimum photosynthesis rates between sunny and cloudy days.

\subsection{Analysis of Respiration with Two Sampling Times}

The amount of the respiration rate did not differ significantly between the two sampling times at 1 and 2 hours after sunset Figure 4 . Therefore, $1 \mathrm{~h}$ was selected for subsequent studies. A study on rose plants (Rosa hybrida) by [31] indicated that gas exchange (respiration rate) increased with fully expanded, young and sunlit leaves. Whilst [32] indicated that rose plants (Rosa hybrid L.) exposed to long photoperiods will be photosynthetically more active and in turn 


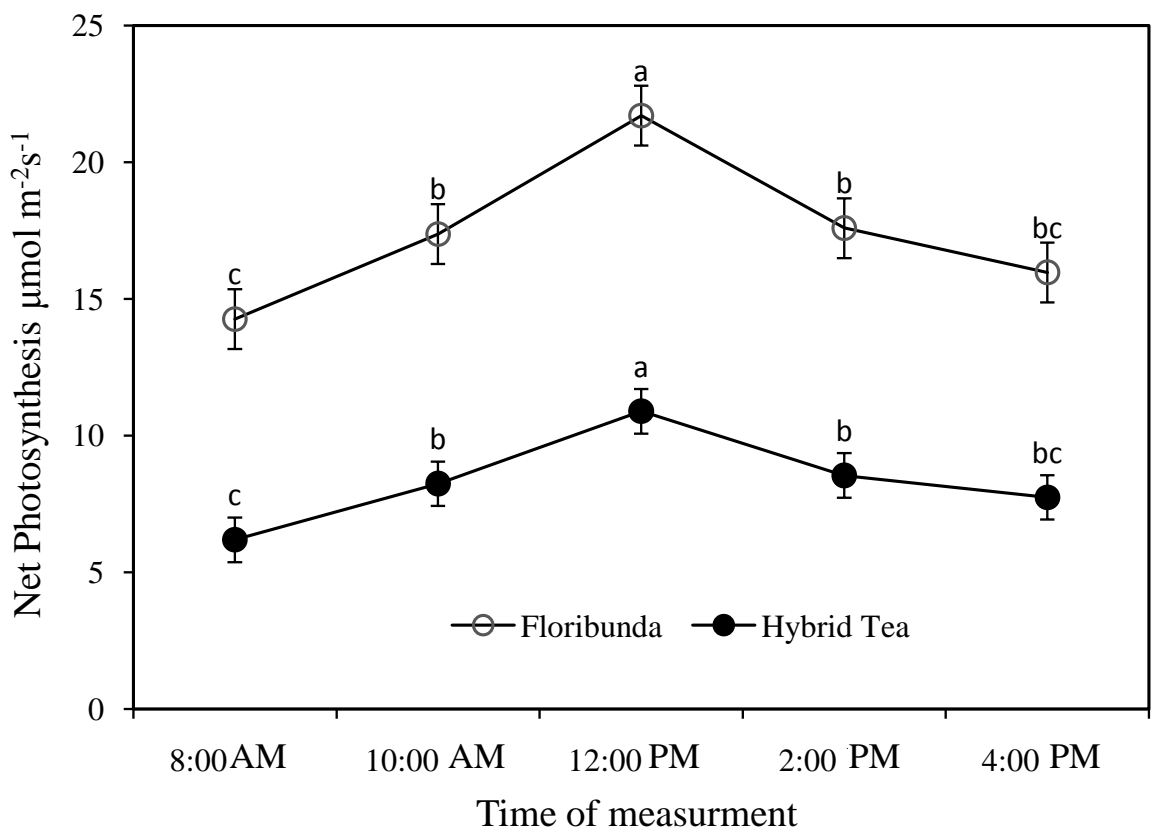

Figure 2. The effect of different sampling times on photosynthesis rate during different periods of the day for both rose varieties (error bars were LSD at $\mathrm{P} \leq 0.05$ ).

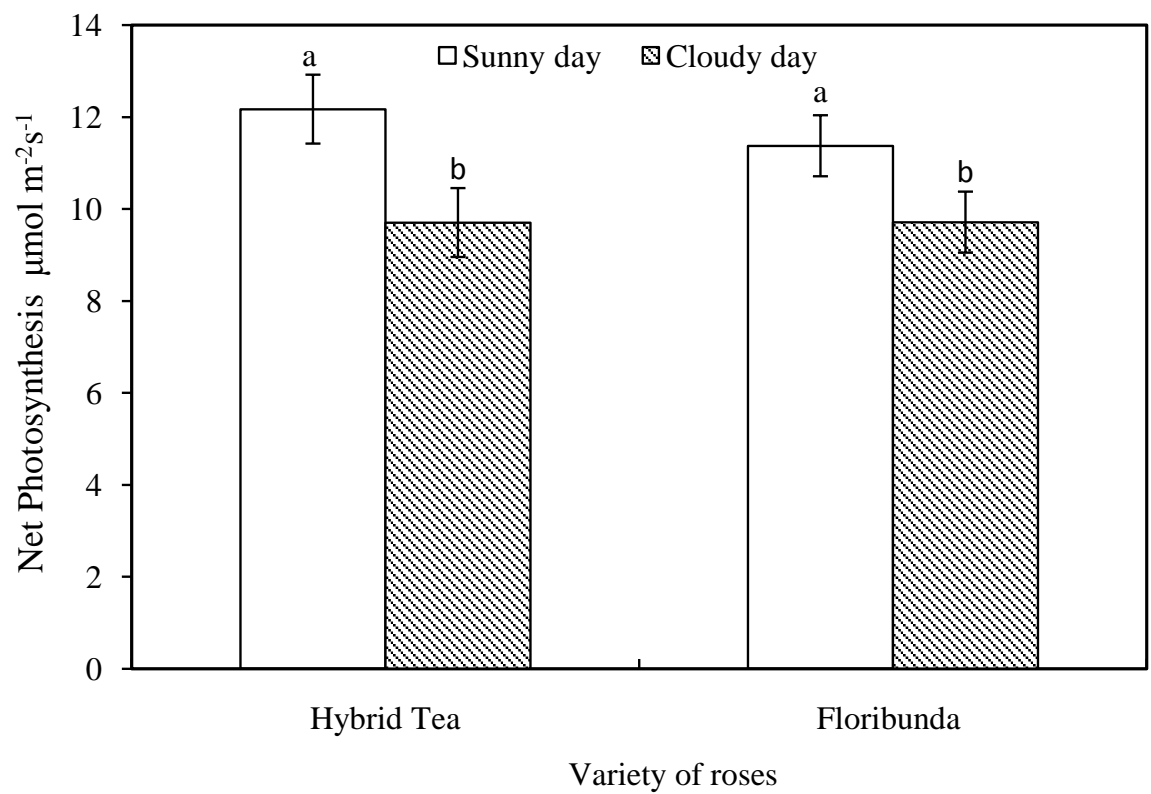

Figure 3. Response of photosynthesis rate to changing weather conditions for two rose varieties (error bars were LSD at $\mathrm{P} \leq 0.05$ ).

will have increased respiration rates. In contrast, [33] indicated that increasing light intensity (the photonic substrate) inhibited respiration in algae. Furthermore, respiration rate in tobacco leaves was inhibited by light, while exposure to darkness after a period of light also result in an increased of release of $\mathrm{CO}_{2}$ exchange and increased respiration rate [34]. Whilst [35] demonstrated that the dark respiration rate increased with increasing leaf area, as demonstrated by the $\mathrm{CO}_{2}$ levels released from plant leaves. Similarly, dark respiration rate increased 


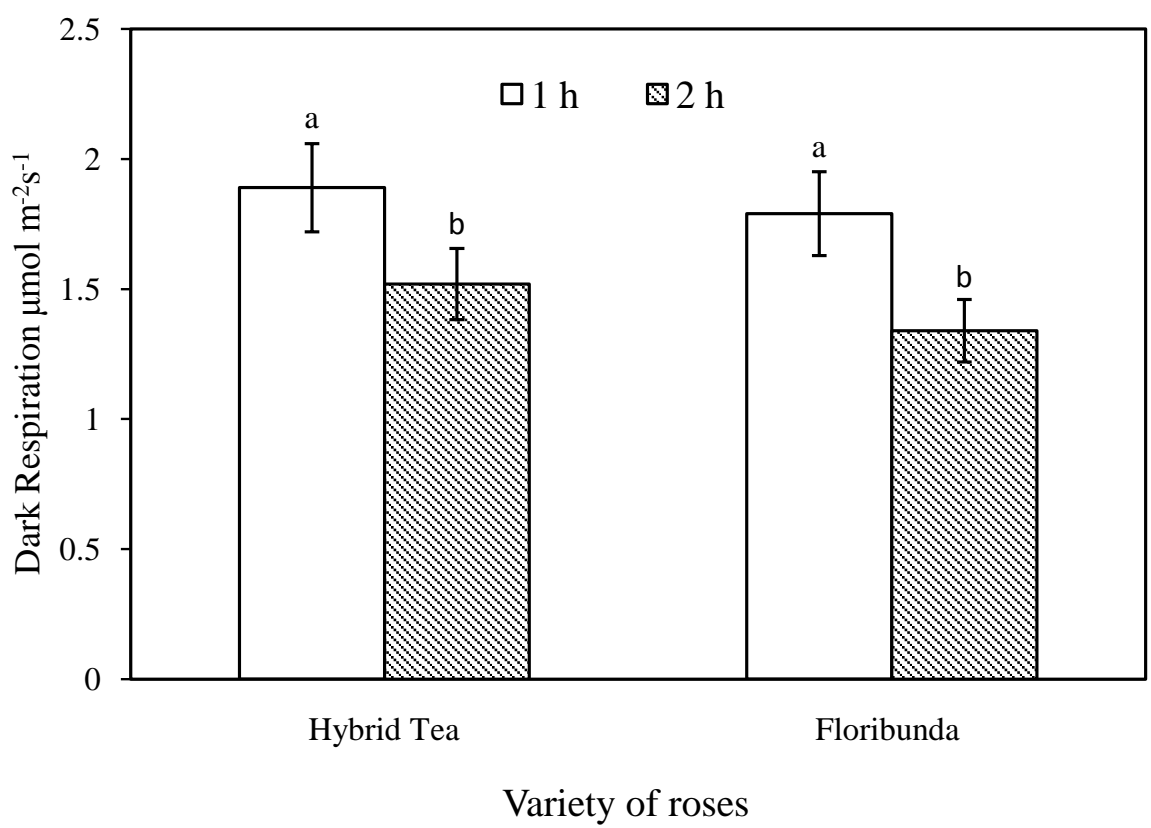

Figure 4. Effect of sampling times on dark respiration rate of leaves of both rose varieties (error bars were LSD at $\mathrm{P} \leq 0.05$ ).

with fully expanded white poplar leaves during respiration measurements [36]. To date, no work has been done on optimizing the sampling times for measuring dark respiration rate in rose plants.

\subsection{Effect of Different Sampling Times on Chlorophyll Content}

Three sampling times (10 am, $12 \mathrm{pm}$ and $2 \mathrm{pm})$ were used to measure the chlorophyll content, and $12 \mathrm{pm}$ was determined as the best time since it gave a high level of chlorophyll content Figure 5. The chlorophyll content increased significantly from $10 \mathrm{am}$ to $12 \mathrm{pm}$ and then decreased by $2 \mathrm{pm}$. Many factors affect chlorophyll content in leaves, these include light, weather conditions and leaf area. In rose plants (Rosa hybrida cv. Habari), total chlorophyll content decreased with low light exposure, shade or cloudy day and with small leaves areas, and in turn increased with high light levels and with increasing leaf area [10]. Furthermore, [37] indicated that chlorophyll content increased with light intensity at $1500 \mu \mathrm{mol} \cdot \mathrm{m}^{-2} \cdot \mathrm{s}^{-1}$ during daylight and with fully intact leaves of Satureja khuzestanica plants. Whilst [17] reported that using $700 \mu \mathrm{mol} \cdot \mathrm{mol}^{-1}$ light intensity on rose plants (Rosa hybrida cv. First red and Twing) increased chlorophyll content. Moreover, [24] showed that increasing light intensity and sun light increased the chlorophyll content for rose plants (Rosa rugosa). Recently, [20] showed that chlorophyll content increased with increasing the light on marigold plants, and for Ficus banjamina L. [38].

\section{Conclusion}

In conclusion, this study showed that light intensity of $1200 \mu \mathrm{mol} \cdot \mathrm{m}^{-2} \cdot \mathrm{s}^{-1}$ gave the most efficient photosynthesis rates in Hybrid Tea and Floribunda roses. Whilst, 


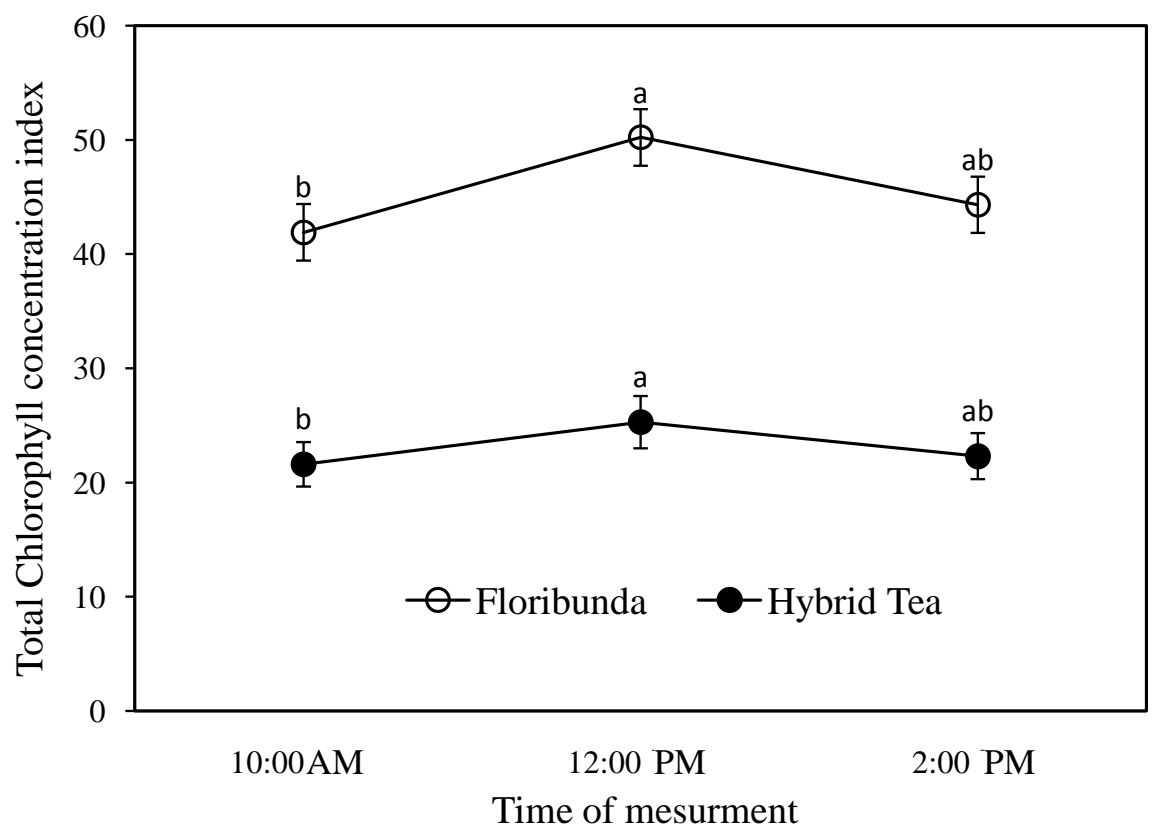

Figure 5. Analysis of different sampling times on chlorophyll content of leaves of both rose varieties (error bars were LSD at $\mathrm{P} \leq 0.05$ ).

$12 \mathrm{pm}$ was the optimal sampling time for high level of photosynthesis in both rose varieties, and sunny days were much better than cloudy days obtaining high rates of photosynthesis. For respiration rate, 1 hour after darkness was determined to be suitable for measuring dark respiration. Finally, the optimum chlorophyll content in both rose varieties was obtained at $12 \mathrm{pm}$. It is recommended that future studies use these optimized parameters in order to obtain robust and reproducible results.

\section{Acknowledgements}

The authors would like to thank Iraqi Government via the Higher Committee for Education Development for scholarship to the senior author. We also thank James Newman from Murdoch University for technical assistance, and Charles Obiero for statistical support.

\section{References}

[1] Kandil, M., Shalaby, A. and Mahgoub, H. (2007) Effect of Some Growth Regulators on the Levels of Endogenous Hormones Chemical and Constituents of Rose Plant. American-Eurasian Journal of Agricultural \& Environmental Sciences, 2, 720-730.

[2] Scalliet, G., Piola, F., Douady, C.J., Réty, S., Raymond, O., Baudino, S., Bordji, K., Bendahmane, M., Dumas, C., Cock, J.M. and Hugueney, P. (2008) Scent Evolution in Chinese Roses. Proceedings of the National Academy of Sciences, 105, 5927-5932. https://doi.org/10.1073/pnas.0711551105

[3] Joichi, A., Katsuyuki, Y., Kenichi, A. and Yoshihiro, U. (2005) Volatile Components of Tea-Scented Modern Roses and Ancient Chinese Roses. Flavour and Fragrance Journal, 20, 152-157. https://doi.org/10.1002/ffj.1388

[4] Guterman, I., Dafny-Yelin, M., Shalit, M., Emanuel, M., Shaham, N., Piestun, D., 
Zuker, A., Ovadis, M., Lavi, M. and Lavid, N. (2002) An Integrated Genomic Approach to Discovering Fragrance-Related Genes in Rose Petals. Flowering Newsletter, 32, 31-37.

[5] Myers, M. (2013) Midwest Gardener's Handbook: Your Complete Guide: Select-Plan-Plant-Maintain-Problem-Solve-Illinois, Indiana, Iowa, Kansas, Michigan, ... North Dakota, Ohio, South Dakota, Wisconsin. Cool Springs Press, Minneapolis, 19-154.

[6] Broertjes, C. (2012) Application of Mutation Breeding Methods in the Improvement of Vegetatively Propagated Crops. Elsevier, Amsterdam.

[7] Ibrahim, M., Manjree, A., Giles, H. and Yonglin, R. (2017) Optimized Method to Analyse Rose Plant Volatile Organic Compounds by HS-SPME-GC-FID/MSD. Journal of Biosciences and Medicines, 5, 13-31. https://doi.org/10.4236/jbm.2017.53003

[8] Kim, S., Kenneth, S. and Heinrich, L. (2004) Bending Alters Water Balance and Reduces Photosynthesis of Rose Shoots. Journal of the American Society for Horticultural Science, 129, 896-901.

[9] Baille, A., Gutierrez, P. and Gonzalez-Real, M. (2006) Analysis of Intercepted Radiation and Dry Matter Accumulation in Rose Flower Shoots. Agricultural and Forest Meteorology, 137, 68-80. https://doi.org/10.1016/j.agrformet.2006.02.010

[10] Matloobi, M., Ebrahimzadeh, A., Khaligi, A. and Hasandokht, M. (2009) Training System Affects Whole Canopy Photosynthesis of the Greenhouse Roses (Rosa hybrida 'Habari'). Journal of Food, Agriculture \& Environment, 7, 114-117.

[11] Walters, R.G. (2005) Towards an Understanding of Photosynthetic Acclimation. Journal of Experimental Botany, 56, 435-447. https://doi.org/10.1093/jxb/eri060

[12] Kool, M.T. and Lenssen, E.F. (1997) Basal-Shoot Formation in Young Rose Plants: Effects of Bending Practices and Plant Density. Journal of Horticultural Science, 72, 635-644. https://doi.org/10.1080/14620316.1997.11515553

[13] Kim, S. and Lieth, J.H. (2003) A Coupled Model of Photosynthesis, Stomatal Conductance and Transpiration for a Rose Leaf (Rosa hybrida L.). Annals of Botany, 91, 771-781. https://doi.org/10.1093/aob/mcg080

[14] Reich, P.B., Michael, B.W., David, S.E., James, M.V., John, C.V., Charles, G. and William, D.B. (1998) Relationships of Leaf Dark Respiration to Leaf Nitrogen, Specific Leaf Area and Leaf Life-Span: A Test across Biomes and Functional Groups. Oecologia, 114, 471-482. https://doi.org/10.1007/s004420050471

[15] Kader, A.A. (2013) Postharvest Technology of Horticultural Crops-An Overview from Farm to Fork. Ethiopian Journal of Science and Technology, 1, 1-8.

[16] Monteiro, J.A., Terril, A.N. and James, E.B. (1991) Potted Chrysanthemum Longevity Affected by Flower Respiration and Carbohydrates. HortScience, 26, 785-785.

[17] Urban, L., Barthélémy, L., Bearez, P. and Pyrrha, P. (2001) Effect of Elevated $\mathrm{CO}_{2}$ on Photosynthesis and Chlorophyll Fluorescence of Rose Plants Grown at High Temperature and High Photosynthetic Photon Flux Density. Photosynthetica, 39, 275-281. https://doi.org/10.1023/A:1013753208917

[18] Jiao, J., Tsujita, M.J. and Grodzinski, B. (1991) Influence of Temperature on Net $\mathrm{CO}_{2}$ Exchange in Roses. Canadian Journal of Plant Science, 71, 235-243. https://doi.org/10.4141/cjps91-033

[19] Calatayud, A., Dolors, R., Elisa, G. and Pedro, F.M. (2007) Light Acclimation in Rose (Rosa hybrida cv. Grand Gala) Leaves after Pruning: Effects on Chlorophyll a Fluorescence, Nitrate Reductase, Ammonium and Carbohydrates. Scientia Horticulturae, 111, 152-159. 
[20] Sardoo, S.F. (2016) Response of Plant Growth Regulators on Leaf Photosynthetic Pigments of Pot Marigold. World Journal of Pharmacy and Pharmaceutical Sciences, 5, 198-205.

[21] Frak, E., Xavier, L.R., Peter, M., Erwin, D., Gaëlle, J., Saint-Joanis, B. and Wendler, R. (2001) Changes in Total Leaf Nitrogen and Partitioning of Leaf Nitrogen Drive Photosynthetic Acclimation to Light in Fully Developed Walnut Leaves. Plant, Cell \& Environment, 24, 1279-1288. https://doi.org/10.1046/j.0016-8025.2001.00784.x

[22] Moriana, A., Villalobos, F.J. and Fereres, E. (2002) Stomatal and Photosynthetic Responses of Olive (Olea europaea L.) Leaves to Water Deficits. Plant, Cell \& Environment, 25, 395-405. https://doi.org/10.1046/j.0016-8025.2001.00822.x

[23] Kim, S. and Lieth, J.H. (2004) Effect of Shoot-Bending on Productivity and Economic Value Estimation of Cut-Flower Roses Grown in Coir and UC Mix. Scientia Horticulturae, 99, 331-343.

[24] Ueda, Y., Nishihara, S., Tomita, H. and Oda, Y. (2000) Photosynthetic Response of Japanese Rose Species Rosa bracteata and Rosa rugosa to Temperature and Light. Scientia Horticulturae, 84, 365-371.

[25] Samartzidis, C., Awada, T., Maloupa, E., Radoglou, K. and Constantinidou, H. (2005) Rose Productivity and Physiological Responses to Different Substrates for Soil-Less Culture. Scientia Horticulturae, 106, 203-212.

[26] Lieth, J.H. and Pasian, C.C. (1990) A Model for Net Photosynthesis of Rose Leaves as a Function of Photosynthetically Active Radiation, Leaf Temperature, and Leaf Age. Journal of the American Society for Horticultural Science, 115, 486-491.

[27] Zieslin, N. and Yoram, M. (1990) Light on Roses. A Review. Scientia Horticulturae, 43, 1-14.

[28] Chaumont, M., Jean-François, M. and Christine, H.F. (1994) Seasonal and Diurnal Changes in Photosynthesis and Carbon Partitioning in Vitis vinifera Leaves in Vines with and without Fruit. Journal of Experimental Botany, 45, 1235-1243. https://doi.org/10.1093/jxb/45.9.1235

[29] Schindler, C. and Hartmut, K.L. (1996) Photosynthetic $\mathrm{CO}_{2}$-Assimilation, Chlorophyll Fluorescence and Zeaxanthin Accumulation in Field Grown Maple Trees in the Course of a Sunny and a Cloudy Day. Journal of Plant Physiology, 148, 399-412.

[30] Michael, D.A., Dickmann, D.I., Isebrands, J.G. andNelson, N.D. (1990) Photosynthesis Patterns during the Establishment Year within Two Populus Clones with Contrasting Morphology and Phenology. Tree Physiology, 6, 11-27. https://doi.org/10.1093/treephys/6.1.11

[31] Lieth, J.H. and Soo-Hyung, K. (2001) Parameterization and Testing of a Coupled Model of Photosynthesis-Stomatal Conductance for Greenhouse Rose Crop. In IV International Symposium on Models for Plant Growth and Control in Greenhouses: Modeling for the 21st Century-Agronomic and 593, 113-120.

[32] Monteiro, J.A., Terril, A.N. and James, E.B. (2001) Postproduction of Potted Miniature Rose: Flower Respiration and Single Flower Longevity. Journal of the American Society for Horticultural Science, 126, 134-139.

[33] Murray, P.M., Siobhan, M., Catherine, C., Tanya, B., Olivier, P., Thomas, P., Alysson, W.F., Fernando, S., Nobre, S., Ifeloju, O., Owoyemi, F.C., Pagnocca, L.D., Sette, E.M., Eric, C., Paula, P.L., Gumersind, F.M., et al. (2013) Sustainable Production of Biologically Active Molecules of Marine Based Origin. New Biotechnology, 30, 839-850.

[34] Atkin, O.K., John, R.E. and Katharina, S. (1998) Relationship between the Inhibition of Leaf Respiration by Light and Enhancement of Leaf Dark Respiration Following Light Treatment. Functional Plant Biology, 25, 437-443. 
[35] Poorter, H., Roger, M., Gifford, P., Kriedemann, E. and Wong, S.C. (1992) A Quantitative-Analysis of Dark Respiration and Carbon Content as Factors in the GrowthResponse of Plants to Elevated $\mathrm{CO}_{2}$. Australian Journal of Botany, 40, 501-513. https://doi.org/10.1071/BT9920501

[36] Loreto, F., Mauro, C., Csengele, B., Carlo, C., Silvano, F. and Russell, K.M. (2007) The Relationship between Isoprene Emission Rate and Dark Respiration Rate in White Poplar (Populus alba L.) Leaves. Plant, Cell \& Environment, 30, 662-669. https://doi.org/10.1111/j.1365-3040.2007.01648.x

[37] Esk, M. and Ali, E. (2013) Effects of 28-Homobrassinolide on Growth, Photosynthesis and Essential Oil Content of Satureja khuzestanica. International Journal of Plant Physiology and Biochemistry, 5, 36-41. https://doi.org/10.5897/IJPPB11.064

[38] Salehi, S., Ali, P.R. and Afshar, F.I. (2014) Stimulatory Effect of Gibberellic Acid and Benzyladenine on Growth and Photosynthetic Pigments of Ficus benjamina L. Plants. International Journal of Advanced Biological and Biomedical Research, 2, 34-42. 